\title{
The effect of bacterial inoculum on the qualitative characteristics, ruminal degradability and PDI content of Lolium multiflorum silage
}

\author{
F Infascelli, MI Cutrignelli, T Di Lella \\ Dipartimento di Scienze Zootecniche dell'Universita di Napoli "Federico II", via F Delpino 1, 80137 Napoli, Italy
}

Many breeding farms in the Campania region of Italy are adopting the practice of growing Lolium multiflorum forage crop, after the harvest of maize for silage. This practice allows harvesting at 3 to 4 stages of growth maturity, totalling up about $20 \mathrm{t} \mathrm{DM} / \mathrm{ha}$, with irrigation generally necessary only after the penultimate harvest. The high rainfall of early spring does not always allow optimal pre-drying. The aim of this study was to estimate the qualitative characteristics change and PDI content (Susmel et al, 1991, Liv Prod Sci, 27, 157-175) of silage, after a bacterial inoculum was added (Lactobacillus plantarum, CSL stocks, $125 \times$ $1010 \mathrm{UFC} / \mathrm{tons}$ of forage). The $3 \mathrm{rd}$ cut of tetraploid Lolium multiflorum Westerwoldicum breed was harvested at the earing stage in the 2nd decade of April, roughly chopped (10-15 $\mathrm{cm}$ ) after natural pre-drying (24 h ; DM : around $28 \%$ ), and was stored for $40 \mathrm{~d}$ in 2 clamp silos : one without inoculum (W), the other with inoculum (L). The analyses (Dulphy et al, 1975, Ann Zootech, 24, 743-756 ; Canale et al, 1983,
Atti SISVet, 37, 487) and the determinations of in situ degradability ( $\varnothing$ rskov and MacDonald, 1979, J Agric Sci, 92, 499-503) were performed on samples withdrawn $5 \mathrm{~d}$ after the opening of the silos. Bags containing silage were incubated in the rumen of 5 rams (fed a diet with forage/concentrate ratio of 3 and $\mathrm{CP}$ content $12 \%$ ) for $6,10,16,24,48,72$ and $120 \mathrm{~h}$. For all other methodological information, see : Commissione proteine nella nutrizione e nell'alimentazione dei poligastrici (1994, Zoot Nutr Anim, 20, 331 -341).

The bacterial inoculum decreased the percentages of soluble $\mathrm{N}$ and $\mathrm{NH} 3-\mathrm{N}$ and improved the fermentation characteristics (lower content of acetic and butyric acids, large increase in lactic acid). Moreover, it reduced $(P<0.05)$ crude protein and non protein dry matter (NPDM) degradability $(P<0.01)$. The PDIE content of both silages was higher than PDIN content. The $\mathrm{L}$ silage had the most favorable content of PDI $(\mathrm{P}<0.01)$.

\begin{tabular}{|c|c|c|c|c|c|c|c|c|c|c|c|c|}
\hline & \multirow{2}{*}{$\begin{array}{l}\text { total } \mathrm{N} \\
(\% \mathrm{DM})\end{array}$} & \multirow{2}{*}{\multicolumn{2}{|c|}{ sol $\mathrm{N} \mathrm{NH}_{3}-\mathrm{N}$}} & \multirow[t]{2}{*}{ CF } & \multirow{2}{*}{\multicolumn{2}{|c|}{$\begin{array}{c}\begin{array}{c}\text { Acetic } \\
\text { acid actic } \\
\text { acid }\end{array} \\
(\mathrm{g} / \mathrm{kg} \mathrm{DM})\end{array}$}} & \multirow[t]{2}{*}{$\begin{array}{l}\text { Butyr } \\
\text { acid }\end{array}$} & \multicolumn{2}{|c|}{$\begin{array}{c}\text { Degradability } \\
(\%)\end{array}$} & PDIA & PDIE & PDIN \\
\hline & & & & & & & & $N$ & NPDM & & $\mathrm{g} / \mathrm{kg}$ DN & \\
\hline W & 1.6 & 55.1 & 13.6 & 278 & 42.7 & 51.8 & 4.1 & $73.8^{a}$ & $61.1^{A}$ & $13.9 \mathrm{~B}$ & $84.8^{A}$ & $64.6^{\mathrm{B}}$ \\
\hline $\mathrm{L}$ & 1.9 & 51.8 & 9.8 & 275 & $\begin{array}{l}18.6 \\
-\end{array}$ & 105.9 & 1.9 & $70.5^{b}$ & $49.8^{8}$ & $18.4^{A}$ & $76.3^{\mathrm{B}}$ & $75.4 \mathrm{~A}$ \\
\hline
\end{tabular}

Financial support by Ministry of University and Scientific Research (40\%). 